\title{
Comment
}

\section{Some Reflections on Recent Developments in the Law of the Sea*}

\section{Shigeru Oda ${ }^{\dagger}$}

I am very pleased to take this opportunity to express, as one of the very few "survivors" of the 1958 Law of the Sea Conference in Geneva, my personal views on recent developments in the law of the sea. In a world where human needs are expanding rapidly, the importance of developing an appropriate international legal regime for managing the food and mineral resources of the world's oceans cannot be overestimated.

\section{What Has tHE DEVELopMENT OF THE LAW OF THE SEA ACHIEVED DURNG THE PAST 50 YEARS?}

\section{A. UNCLOS I-1958. The Emergence of the Concept of the Continental Shelf.}

In the light of the claim to the continental shelf initiated by the United States in 1945 and the demand by some Latin American countries for the expansion of fishery jurisdiction off their coasts, the trend of systematizing jurisdiction over sea resources, especially oil and fish, off the coast provided the motive for holding the first Law of the Sea Conference in Geneva, from February through April 1958. That conference gave birth to the four Geneva Conventions on the Law of the Sea, including the Convention on the Continental Shelf. ${ }^{1}$ However, that Conference failed to fix the limit of the territorial sea or to adopt the concept of exercising fishery jurisdiction in offshore areas.

\footnotetext{
Adapted from comments delivered at a colloquium held in Brest, France, on 19 May 2000 on the subject of the law of the sea, entitled "Droit de la mer et pêche responsable."

$\dagger \quad$ Judge of the International Court of Justice, 1976-present. LL.M 1952, J.S.D. 1953, Yale Law School. Yale Law School Citation of Merit, 1997.

1. Convention on the Continental Shelf, Apr. 29, 1958, 15 U.S.T. 471, 499 U.N.T.S. 311; Convention on Fishing and Conservation of the Living Resources of the High Seas, Apr. 29, 1958, 17 U.S.T. 138, 559 U.N.T.S. 285; Convention on the High Seas, Apr. 29, 1958, 13 U.S.T 2312, 450 U.N.T.S. 82; Convention on the Territorial Sea and the Contiguous Zone, Apr. 29, 1958, 15 U.S.T. 1606, 516 U.N.T.S. 205.
} 
B. UNCLOS II-1960. Failure.

Despite five weeks of negotiations, the second U.N. Conference on the Law of the Sea, from March through April 1960, completely failed to adopt a territorial-sea limit. ${ }^{2}$

\section{UNCLOS III-1974 to 1982.}

After UNCLOS II, movement by States towards expansion of jurisdiction over offshore areas gave birth to the movement for a new law of the sea. It led ultimately to the third Law of the Sea Conference in the years 1973 through 1982. At the conclusion of this conference in December 1982, the nations of the world, in the 1982 U.N. Law of the Sea Convention, ${ }^{3}$ agreed upon four key elements:

(1) THE 12-Mile TERRITORIAL SEA. ${ }^{4}$

(2) THE REDEFINITION OF THE CONTINENTAL SHELF. ${ }^{5}$ Technical improvements in drilling for submarine petroleum in deeper waters brought a new definition of the continental shelf. Where once it had been fixed at a depth of 200 meters, now the continental shelf was defined as extending "to the outer edge of the continental margin, or to a distance of 200 nautical miles."

(3) THE NEW CONCEPT OF THE EXCLUSIVE ECONOMIC ZONE. ${ }^{7}$ The demand for offshore fisheries also gave rise to the concept of the exclusive economic zone extending to the same distance of 200 miles.

(4) FREE PASSAGE OF MILITARY VESSELS AND AIRCRAFT IN ARCHIPELAGIC WATERS AND STRAITS. ${ }^{8}$ In the movement towards the expansion of coastal jurisdiction over offshore sea areas, it was of vital interest to the United States to ensure that this expansion of coastal jurisdiction did not interfere with the free maneuver of its warships and military aircraft in offshore areas of other countries. As a result of a compromise reached between the United States and certain coastal States (mainly developing nations), a new concept

2. Second United Nations Conference on the Law of the Sea, Official Records, Summary Records of Plenary Meetings and Meetings of the Committee of the Whole, U.N. Doc. A/CONF.19/8 (1960).

3. United Nations Convention on the Law of the Sea, Dec. 10, 1982, 1833 U.N.T.S. 3 [hereinafter 1982 Convention].

4. Id. art. 3 .

5. Id. art. 76 .

6. Id.

7. Id. art. 57.

8. Id. arts. 37-54. 
of free passage of military vessels and aircraft through archipelagic waters or straits emerged.

D. A Legacy of Limited Achievements.

Apart from certain detailed technical provisions, achievements in the development of the law of the sea during the past 50 years have, in principle, been limited solely to the four elements mentioned above.

\section{WHAT, THEN, HAS NOT BEEN SOLVED BY THE NEW LAW OF THE SEA?}

\section{A. Dividing the Sea Area: Maritime Delimitation.}

There is, in general, conflict over coastal jurisdiction between neighboring or opposite States. This is a question of delimitation of the maritime boundary or, in other words, the division between neighboring or opposite coastal States of the sea area into zones of exclusive control of each coastal State. The 1982 U.N. Law of the Sea Convention provided no clear definition of this matter. Neither the expression "justified by special circumstances," as used in the 1958 Continental Shelf Convention to determine the delimitation of the continental shelf between opposite or adjacent States, nor the expression "in order to achieve an equitable solution,"10 as used in the 1982 U.N. Convention to define the boundary of both the exclusive economic zone and the continental shelf, affords any objective criterion other than the concept of equity. The maritime boundary thus cannot be clearly defined in legal terms. Therefore, the division of the geographical area cannot be subject to judicial determination.

\section{B. Sharing the Benefits Gained From the Common Heritage of Mankind.}

There is a question concerning the ocean area beyond the national jurisdiction of States. The classical concept held that this area was part of the high seas, where the principle of freedom of the high seas governed.

(1) DEEP SEABED. In order to prevent the unlimited expansion of the definition of the continental shelf, there emerged the concept of the "common heritage of mankind" as applied to the deep seabed. ${ }^{11}$ No longer would the resources of the deep ocean be subject to free market principles of acquisition, control, and profit. Rather, the benefits arising from these resources would be shared. Whether this concept meant that the developing nations, which did not contribute to the exploitation of the hard mineral resources of the seabed, should still enjoy a share of certain benefits from that exploitation, or that priority should be given to protecting the investment made in that exploitation by the developed nations, a compromise was reached via the establishment of

9. Convention on the Continental Shelf, supra note 1, art. 6.

10. 1982 Convention, supra note 3 , arts. 74, 83.

11. Id. art. 136. 
the very complicated regime of the "Area," namely, the deep seabed. ${ }^{12}$ This compromise came at a time when the actual exploitation of hard minerals in the deep seabed was still, in practice, far in the future, and it was thus not really necessary then to set up large-scale institutions such as the International Seabed Authority or the International Tribunal for the Law of the Sea (ITLOS).

(2) OCEAN FISHERIES. In 1979, I had already suggested, in a lecture delivered in New York, that the idea of the "common heritage of mankind," though originally applied only to the hard mineral resources of the seabed, would eventually apply to the fisheries in the vast ocean realm. I also said that this would eventually require discussion at a further conference on the law of the sea. This became a reality, as a new conference on fisheries was convened by the United Nations from 1993 to 1995 and produced the 1995 U.N. Fish Stock Agreement. ${ }^{13}$ That Agreement does not, however, actually address the real questions of international fisheries. In this respect, I must point out that in the case of fishery resources, which are renewable resources, the maximum sustainable yield constitutes a limit on the harvesting of the resource. For fisheries, the conservation aspect is of primary importance; this is in contrast to the case of exploitation of hard minerals, where no such limit is imposed.

(3) SHARING THE BENEFITS, IN GENERAL, OF THE COMMON HERITAGE OF MANKIND. The main difficulty since the 1960 s has been the method of sharing the benefits derived from the exploitation of hard minerals in the seabed and ocean fisheries in the areas beyond the national jurisdiction of States. These benefits have come to be known as the "common heritage of mankind." Given the fact that each State will naturally attempt to maximize its share of the available portion of this limited resource, the question of how the demand of each State should be regulated or controlled remains open. Neither the 1982 Convention nor the 1995 U.N. Fish Stock Agreement (in the case of ocean fisheries) offers a solution to the difficulty involved in the sharing of the ocean resources. This is not due, however, to any failure on the part of international law itself, since the sharing of resources is a matter of equity and politics and, thus, not subject to judicial determination. There exists, as yet, no regime that can control or manage these elements. In practice, the solution could be sought on a case-by-case basis in light of what equity actually requires of those States who will share these resources.

12. Id. Part XI.

13. Agreement for the Implementation of the Provisions of the United Nation Convention on the Law of the Sea of 10 December 1982 Relating to the Conservation and Management of Straddling Fish Stocks and Highly Migratory Fish Stocks, 6th Sess., U.N. Doc. A/CONF.164/37 (1995), reprinted in 34 I.L.M. 1542 (1995). 
C. Sharing the Burden in the Development of the Resources: Preservation of the Marine Environment.

There is one more point that should not be overlooked: preservation of the marine environment. In order to preserve and protect the environment, it becomes necessary to regulate and restrict the use of the ocean. If exploitation of sea resources represents a positive point, environmental preservation represents a negative point in that the use of the ocean must be reduced. The question is how to address the sharing of this burden of restricted use of the ocean. Once again, the question raised is one of equity and not of legal norms.

\section{CONCLUSION: THE THREE MAIN ISSUES THAT NEED TO BE RESOLVED}

The preceding comments have provided a condensed review of past developments. Looking forward, I suggest that the following three issues remain open and in need of resolution:

(1) conflicting maritime delimitation claims to wider coastal sea areas for each State's exclusive use;

(2) the sharing of the benefits of the positive use of the ocean;

(3) the sharing of the burden of restrictions on the use of the ocean, imposed for the purpose of preserving the marine environment.

In all of these, the concept of equity has a predominant impact, while legal norms play little or no role. Equity comprises no objective legal criterion and varies in each circumstance. Its evaluation or determination is not a simple matter. Solutions in the above categories nonetheless will need to be found; but they will not be found simply in rules and regulations of law, and they are not subject simply to judicial determination. 
